\title{
DUCACHES IN THE UKRAINIAN CULTURE AREA
}

\author{
Katya Volik \\ volikkatya@rambler.ru \\ Vasyl Stefanyk Precarpathian National University, \\ Ukraine
}

\begin{abstract}
The report describes the emergence (origin) and distribution of dukachey in the Ukraine, their popularity and distribution, and why they have been largely forgotten.

The report examines dukach - traditional ukrainian folk decoration. It is considered one of the branches of folk art - namely, the tradition of folk ornaments in the example of ducats.

It examines the role of dukachey in the material and spiritual life of the Ukrainians. Appeal to the national art and national traditions is a means of creating a cultural identity and national consciousness.

The influence of cultural traditions dukacha Ukrainians. The diversity of national cultures enriches the culture of the world, and shows the universal and the particular, inherent in a particular culture.

The report investigates the artistic means of the expression of dukachey based on technical and technological characteristics of the production of coin-dukachey.

Key words: Dukach, Ukraine, culture, folk decoration, tradition
\end{abstract}

\section{INTRODUCTION}

Global market distribution and advertising impose certain standards of fashion, behavior, values, etc. However, it is the variety of national cultures that enrich world culture, highlight the universal and the individual, peculiar to a certain culture. Fully-fledged existence beyond the national culture is impossible, so resorting to the national art and national traditions is a means of shaping a cultural personality and national identity.

The objective of the research is to identify the role of ducaches in the Ukrainian material culture and their functioning in people's everyday life. The subjectmatter of the research is the role of ducaches in the traditional Ukrainian people's culture. The object-matter of the research is ducaches.

Chronological and geographical borders are determined both by active existence of ducaches in the system of traditional national adornments and by their availability in the modern Ukrainian museums and private collections.

The theoretical scientific background covers papers of researchers of our country, in particular, those containing information about ducaches. The practical background includes comprehensive analysis of ducaches as objects of material culture. 


\section{FINDINGS}

The ducach is a national Ukrainian adornment in the form of a decorated coin being part of the traditional costume ensemble. It should be noted that the custom of stringing coins and using these strings in costumes is popular with many nations. However, it was mainly in the central and eastern regions of Ukraine that the tradition of using a single coin decorated with curls, metal bows and semi-precious stones emerged. A ducach is usually complemented with coral beads, and it was quite frequent for three ducaches to be used at a time.

The famous researcher S. Taranushenko commented on the only fundamental research dealing exclusively with ducaches as follows: "The monograph of I.G. Spasky Ducats and Ducaches of Ukraineis was the first to scientifically highlight an important realm of Ukrainian art -making of ducaches" (Spasky, 1970, p. 5). At the same time, S. Taranushenko noted that "I.G. Spasky was a numismatist, and his paper concerned solely historic and numismatic research. The major part of the monograph published in 1970 dealt with the historic systematization of ducats and ducaches" (Spasky, 1970, p. 7). In this paper, Spasky defined the ducach as a metal, often gilded adornment worn on the breast, a typical detail of the Ukrainian woman's costume, a work of the art of local jewelers (Spasky, 1970, p. 5).

Naturally, I. Spasky has done done time-consuming and laborious work. He dedicated over thirty years to studying numismatics and described over 850 ducaches with sketches and photos attached, and systematized and compared ducaches with many European coins.

It was not until the early 21st century that new investigations concerning ducaches appeared. The researcher G. V. Vorochynska dedicated a section of her book Ukrainian National Woman's Adornments of the 19th - Early 20th Century to metal adornments, describing ducaches and their typical construction arrangements, compositional types, ideological background, as well as techniques of metal adornment manufacture (Vorochynska, 2007).

Yu. P. Derevianko, S.M. Pazynich, O.S. Ponomariov in the section Ducaches as the Pearl of Folk Art of their book Aesthetic Ideals of the Nation's Cultural Heritage investigate the aspect of safeguarding national culture in the context of globalization, which increasingly gains spiritual and aesthetic relevance. The gradual oblivion of ducaches in today's world is confirmed by the fact that the term ducach is absent in "(...) dictionaries and different encyclopedias of the 20th - 21st centuries" (Derevianko, 2012 p. 222). The authors also emphasize in their book "(...) that ethnographers previously considered ducaches as a branch of folk art, not getting deeper into the historic and social foundation of this unique phenomenon. Researchers of people's everyday life took no interest in the artistic aspect of ducaches.....nowadays, there are virtually no fundamental artistic and theoretical aesthetically-oriented papers studying these woman's adornments" (Derevianko, 2012 pp. 222-225). This paper further outlines the definition of the ducach and imprints on it, its development, and, finally, disappearance from everyday life.

The book Museum of Ukrainian Folk Art by A.V. Gassanov states as follows in the section describing traditional adornments: “Ducaches became the most widespread 
in the Naddniprianshchyna region. Ducaches were once (17th - first half of the 18th centuries) considered precious objects and suited tastes of the ruling class. In the course of time, aristocrats' adornments penetrated peasants' everyday life and existed as folk adornments until the early 1900s. They were made by Ukrainian goldsmiths working in towns and cities and selling their articles in fairs, markets or local shops" (Vialets, Bilos, 2010, p. 127).

In his collection of leaflets Ukrainian Traditional Woman's Adornment of the 19th20th Centuries. Ducaches, S. V. Kozlov publishes 36 ducach imprints and provides attributes of each ducach, stating that »adornments worn on the breast... are authentic ducaches of eight Ukrainian Regions in the 19th - 20th Centuries«. In the preface, the author defines the ducach and briefly describes the characteristic features of its wearing: »Ducach on a girl's neck was a certain sign of stepping from childhood into maturity. A married woman continued wearing a ducach until her daughter grew up who then inherited the familial woman's adornment «" (Kozlov, 2010a, p. 6)

In the next collection of leaflets Ukrainian Traditional Woman's Adornment of the 19th - 20th Centuries. Beads, S. V. Kozlov publishes images of ducaches on strings of beads emphasizing that "adornments worn on the breast and consisting of several components were especially notable (...) beads, coins - ducaches, crosses, holy pictures" (Kozlov, 2010 b, p. 3).

O. Kosmina writes in the two-volume edition Traditional Ukrainian Costumes, analyzing Ukrainian costumes by regions, did not point out regional peculiarities of ducaches in Ukraine, mentioning only that they were worn as an adornment: "Adornments worn on the neck and the breast were coral beads with ducaches and medallions (lockets with an image of Christ or a saint)" (Kosmina, 2006a, p. 70). The researcher also contrasted the way of wearing a bow with a ducach: "Ducaches and holy pictures were hung on the strings of beads . (...) A ducach with a bow would hang right below the neck on a wide ribbon - a big silver coin attached by three small chains to a big skillfully made brooch. The 'bow' was of different shapes (wicker, horned, Veremiivsk-style, etc.) and was decorated with colorful (mainly red) glass . On its reverse side, it had a staple through which a ribbon was passed". (Kosmina, 2006a, p. 89).

The first Ukrainian ducach bows could have appeared under the influence of Russian high state decoration of the first half of the 18th century, such as Shydlovsky's monarch's kleinods - medals hung to openwork brooches expensively decorated with precious stones (Spasky, 1970, p. 42).

Ducaches with bows were more typical for Left-Bank Ukraine, while in Right-Bank Ukraine ducaches were called silver or gold tsar's coins strung on a colorful cotton lace through a soldered eye (Kosmina, 2006a, p. 89). "Silver or gold coins (ducaches or lychmans) were worn together with beads. Ducaches were presented to the bride at a wedding" (Kosmina, 2006a, p. 103).

The term ducach is supplemented by the term lychman. "The ducat is an adornment in the form of a silver or a gold coin. The ducach with a bow is a woman's adornment in the form of a silver coin hung to a big brooch" (Kosmina, 2006a, p. 133). "Lychmans are the same as ducaches" (Kosmina, 2006a p. 135. "Lychmans are small round metal holy pictures set in a copper rim. Mentalyks are metal round badges or 
coins" (Kosmina, 2006b, p. 15). "A woman's adornment worn on the breast in the form of two icons (Annunciation and Resurrection) in a joint silver rim attached by two small chains to a silver or a gilded bow decorated with a red glass insert, was called a lychman" (Kosmina, 2006b, p. 46).

The word ducach is a Ukrainian modification of the well-known name of Western European gold coins - ducats, that broadened its meaning in Ukraine in the 17th century to designate gold medals. This name was initially given to Venetian coins weighing about $3.5 \mathrm{~g}$ put into circulation in 1284 . It is considered that it derived from the word that was part of the coin legend: Sit tibi Cyriste datus quem tu regis iste ducatus. In Ukraine, where money circulation was part of the Polish monetary circulation in the 16th - 17th century (until its joining the Russian Empire), the name ducat did not refer to the Venetian coins, because after the ducat was put into circulation in Western Europe, it designated all coins of the specified weight minted in several countries: in Hungary since 1325, in Germany since 1559 following lighter goldguilders, in Holland since 1586, etc. The most common name for ducat coins in Ukraine and Poland was red gold coins. The population of Ukraine used the Polish and, more generally, Western European coins; the latter especially applies to gold coins and big silver coins - thalers and leucies (levendalers) (Spasky, 1970, p. 27).

Regarding the ducaches that were specially made as woman's adornments, I. G. Spasky came to the conclusion that they were the object of local manufacture with the center in Left-Bank Ukraine (Spasky, 1970, p. 7).

However, despite the significant role of Spasky's monograph, the problem of ducaches classification and attribution has not been comprehensively dealt with so far, which is, in particular, pointed out in O. Romanenko's article. In her article Ducaches: Ukrainina Applied Art, the author defines ducaches, gives an account of one of the manufacturing techniques, describes the shape of a ducach and provides a list of imprints. She also emphasizes that "ducaches are often underestimated - collectors do not often recognize them. (...). The date on the coin used as a mould for the ducach, did not correspond to the time of its making(...) Only professionals can specify the time of ducach manufacture by technological or other signs".

It can be stated now that a large number of ducaches became part of museum collections directly through the peasant's everyday life, and in this respect the exclusive 'right' of ethnography to ducaches is not to be questioned. It is to the ethnographers that we owe the fullest collections and the most thorough documentation. However, ethnographic materials regarding ducaches are characterized by chronological ambiguity (Spasky, 1970, p. 12).

The revolution of 1917 threatened ducaches and their wearing, because many ducaches represented imperial crowns, coats of arms, crowned persons, monarchs' emblems that reminded of the former regime (Spasky, 1970, p. 12).

It is worth mentioning that the word ducach was increasingly used in the meaning of kurkul' (a wealthy peasant) as social struggle was worsening (Spasky, 1970, p. 13). That is ducach referred not only to an adornment made of a coin, but also a wealthy person. These rural rich men were called duca, ducar, and ducach in Ukraine:

Oh, here goes the rich man, oh, here comes the ducach, Mocking: 
- Oh, why, oh, why are the poor

Getting drunk?

Oh, one man grabs the duca by the hair, a second by the hand,

A third man hits the duca's neck:

Oh, do not go there, foe's son,

Where the poor are drinking!

(http:/ / mos-ukr-capella.ru/main.php?file=oi-nastypyla)

Another folk song definitely ascribes the ducach to the signs of wealth (Spasky, 1970, p. 13):

Be damned you with your father - rich man,

May your oxen die and you be with a ducach!

A slightly different variant of the song "Oh, I went to get the sheaves" (http:/ / ensembles.ru/song/oj_poihav.)

May the devils find you, find you

With your ducaches, your ducaches!

May you oxen be all dead, all dead,

And you the evil with ducaches, the ducaches.

Moreover, clothes that were characteristic of the highest social echelon, were an incentive for committing crimes. A case is described when Pelagia, the bank merchant Kamarenko's maidservant, robbed her master, stealing a fur coat, svytka (a coarse heavy caftan), skirts, blouses, veils and some precious adornments - amber beads and ducaches apart from a considerable amount of money (Masliichuck, 2007, p. 326).

The belongings of the wealthy at that time included silver earrings with pearls, gold earrings, with ducaches being mentioned, too (Masliichuck, 2007, p. 296).

Below is a fragment of a comic song of the early 20th century (Derevianko, Panzich, Ponomariov, 2012, p. 226).

Though I'm red and spoilt,

My father is a rich man,

He has grey oxen in his shed,

I have a ducach on my neck.

The distinguishing of ducachs is very important for our research, it concerns not only the trend of wearing ducachs, but also the ways of spending time and different kinds of events connected with different kinds of ducachs. At first ducachs were worn on the bosom as central piece of jewelry by peasants, and then ducachs came into landowners' everyday lives.

The ducachs were ascribed protective properties. For example, ducacs with image of Parasceva Friday. Usually Parasceva was portrayed on a red omophorion with a cross in her hand that was a symbol of martyrdom and, at the same time, of the Crucifixion of the Christ. Sometimes a suckling in her hand, that was said to be given by the Christ (Abramovych, 2002, p. 79).

In some documents ducats (sometimes ducat is not a coin) are mentioned not as coins, but as jewelry. Ducat, ducach is a single piece of jewelry that bids for central place in the ensemble of jewelry that was worn in ears or on the bosom. In the territory of Nizhyn the ducach was worn in this place along with the cross. 
Each hung on a separate strip, but at the same height, obviously hindering each other. The following description of Ukrainian lady's clothes refers to the 40's of the 20th cent.: " $(.$.$) on the neck there always hung a couple of strings of coral or$ other necklace, or strings of coral and a few rows of golden coins with a big silver or golden cross, $(\ldots)$ or a ducat instead of a cross; that was a big golden coin, often an icon or any expensive medallion" (Spasky, 1970, p. 28).

From this quotation it can be seen that in some cases red golden coins, tchervonetzs, ducats and others, that were obviously taken by women as jewelry, if counted in terms of money, expressed in different kinds of property, composed the sum total. One shouldn't be surprised by this fact, as ducat - a coin, hung on the necklace retained its intrinsic value (Spasky, 1970, p. 32).

A document dating back to 1757, in which it is told that a Borzensky priest Mykhailo Butovych, when finishing building a church, gave "for a limy horse his own white one (...). Costing 15 roubles, a ducach of his own and one of his wife, costing 10 roubles" (Spasky, 1970, p. 35)., evidence that ducachs were valued not only as pieces of jewelry, but also as means of payment.

The meaning of women's jewelry, as material assets, can be seen from the old custom of giving to churches coral, pearl necklaces and of golden coins, ducachs and others as pendants for icons (Vorochynska, 2007 p. 25). This was witnessed in the work of the Savior "in the Ukraine, on the so called local image of the Mother of God there hung at least one ducach, whose ribbon was hanging on the halo of the icon" (Spasky, 1970, p. 32).

The ducat reproduced in Catalogue of Ukrainian Antiquities is a gold medal made by one of the most talented European medalists of XVII century, Sebastian Dadler, author of many religious and popular medals. Another ancient name for jewelry - yednus or ahnus, ohnusok is of purely Polish descent. It had not become widespread in Ukraine and probably recurs in naive reasoning about the past of literary hero Mr. Khalyavsky (Spasky, 1970, p. 37).

Ducaches in the XIX and XX centuries already came in different materials and artistic value of women's jewelry - from high rough, but carefully made jewelry to a nickel-and-dime, very primitive factory stamped plate. Accordingly, in some areas of Ukraine ducach at the beginning of the XX century. remained a parade, or festive decoration, while in other areas not only adults but also children wore ducaches every day. Ducach could appear in the garb of a teenage girl just coming into girlhood. Ducach came from the girl's mother, or it had to be ordered or bought somewhere (Spasky, 1970, p. 15).

In 1805 a traveler who compared notes of his stay in Ukraine, noting the extreme poverty of peasants near Yahotyn, at the same time spotted: "her neck outfit with authentic and fake coral often worth much more than the whole house". Peasant "heirloom jewels" were made throughout the generations. Consecrated by unchanging fashion, coral, amber, ducach, cross earrings were handed down from generation to generation and preserved (Spasky, 1970, p. 15).

"Thanks to the sustainability of public fashion, peasant ornaments were handed down from generation to generation and kept as an expensive family heirloom and it all contributed to their long-term preservation" (Vialets, 2010, p. 127). 
The widespread distribution of ducats in the XVIII century among different segments of the population of Ukraine is shown in illustrations of historical work by O.I. Shafonsky, which depicts ducats among the jewellry of famous and ordinary women (Spasky, 1970,p. 41). Not surprisingly, in the XVIII century the spread of popular jewelry began. It formed a new kind of folk art. Goldsmiths, in addition to common jewelry - earrings, rings, crosses, reefs, or buttons to good beads (coral) - produced a new kind of jewelry - ducaches. Thus, the ducaches were a result of a long and complex process of development of the Ukrainian artistic metal plastic (Spasky, 1970, p. 7).

In wide use was a necklace made of round black, milky white, blue and pink glass. In the Kharkiv region to such a necklace were hung one or two ducaches (Vorochynska, 2007, p. 59).

In the Poltava and Kharkiv region oval lattices were also produced that looked like baskets of flowers and leaves. Around the perimeter were placed small floretknots. However lattice-baskets from the Poltava region were different from lattices that were produced by goldsmiths in Lebedyn and the Kharkiv region. The products of Poltava artists were less delicate, to the right and left of the baskets grow massive leaves and few flowers, between leaves in the middle is a depiction of a head with rays. Baskets produced in Lebedyn region are more delicate, lighter, twigs with leaves and flowers flexibly and naturally disperse to the sides and to the top, in the middle between the leaves is a knot with a big piece of glass (Vorochynska, 2007, p. 106).

On the Left Bank of Ukraine necklaces of coins were also made, including in the Poltava region, but more often in the Kharkiv region. Here they were made of silver coins of different diameters, with a connecting chain and decorated with glass and coral pendants. Necklaces of coins had planar-relief ornamental textured graphic and lace work (Vorochynska, 2007, p. 123).

We can distinguish the following types of ducaches by the way of execution:

- ducaches made from genuine coins with soldered eyelet

- ducaches made of genuine medals with soldered eyelet

- ducaches made from genuine coins with soldered eyelet and ribbon

- ducaches made of genuine medals with soldered eye and bow

- $\quad$ replica coins specifically for ducaches

- $\quad$ replica medals specifically for ducaches

There are several techniques of making ducaches:

1) Casting technique

a) Casting technique of the whole ducach at once.

The simplest form of medallions - a medal with an eyelet made by the technique of casting. Eyelet and rim, simulating wire wicker, were cast togehter with a medal. These ducaches were almost never gilded and bows were not attached

b) Casting technique with soldered spring around ducach.

Ducaches in a wire rim, where at the eyelet above the image of one of the sides is a soldered socket, crown, cast with cherub head, etc.. ducaches made of silver often have such a design.

c) Casting technique with soldered spring around and a demure knot. 
Ducaches by casting technique into this form are completely in wire and other types of rim, where on the eyelet above the image of one of the sides is a soldered demure knot, crown, cast cherub head, etc. large silver coins. often have ducaches made of such a design

2) Technology of punching each side separately and soldering.

Medallions are made by a punching technique of each side separately on metal blanks, then the two components are soldered together and soldered to the spring around the medallion and eyelet. These ducaches often repeat stories of oldest western medals.

\section{3) Technique of free coinage.}

Ducach is made from a single piece of metal. This type of ducaches are very rare because they are mostly made of precious metals.

4) Ducaches made of real medals or coins (pendant-medal)

Genuine authentic Western medals of XVII-XVIII centuries and Russian medals of XVIII century are used for medallions. Some originals among Western medals of XVII - XVIII centuries and Russian medals of XVIII century are established for many types of Ukrainian medallions. Some ducaches have significant direct impact on their iconography in Russian-Ukrainian art copper casting (Spasky, 1970, p. 16).

As we see, ducaches were made of different materials: gold, silver, copper, tin, bronze, but more importantly, for a large number of types of medallions as tangible monuments of Ukrainian art, one of major and defining feature is the lack of fixed compositions. Even if goldsmiths created many new types of ducaches, it was mainly by combining different available stamps, ie, forming a kind of "hybrid" with logically un-related compositions, whereas the original medal is made on a single theme, as a story on two "pages” (Spasky, 1970, pp. 16 - 19).

Stamping and molding belong to the types of technology that aims to make a number of similar objects. Therefore, most forged and cast ducaches reached us in repeat versions, but also in isolated instances, we may perceive a group of repetitions that did not reach us [10, p. 16].

I.G. Spassky came to the conclusion that late ducaches actually come from one Russian original of the second half of the XVIII century, which is replicated fully (ie both its sides), or in "hybrid” types, where the second side is an icon of Ukrainian -Russian iconography (St. Paraskeva, Virgin, Golgotha, etc.) (Spasky, 1970, pp. 19-20).

Ducaches made of gold-plated coins (or gold) XVII - XIX centuries - silver roubles, thalers, half roubles are remarkable. Some types of ducaches of Ukrainian production repeat generalized types of a coin. The biggest impressions left as replicas are cross-rubles made at the time of Peter I, Peter II and Paul I with cruciform monogram emblems instead (Spasky, 1970, p. 20).

Ducaches of copper coins are already a decadent phenomenon as scarce medallions of pressed sheet exist in several collections with the words „Ornament for women and young ladies" or even "Ornement des femmes». Since the second half of the XIX century they were made in factories of "vulgar" decorations and transported throughout the Russian Empire (Spasky, 1970, p. 20).

Influenced by brooches or knots that fixed fronts and downside jewelry in separate groups of later medallions of local production we can observe a rejection of placing the image on the reverse side of the medal-pendant (Spasky, 1970,p. 20). 


\section{CONCLUSIONS}

- Comparing complexes of jewelery from different regions of Ukraine, we see our people in the diversity of creative colorful art making,. Ducaches passed from generation to generation and thus preserve the memory of the family. Therefore, communication with a ducach - is not only admiring its form, design and beauty, but also communication with previous generations.

- As coins and medals were used as ducaches, they reflect the historical past of the Ukraine. For example the image of imperial rulers, or various national holidays and events. We take part in the era, thus establishing a connection with the entire history of the people.

- It is also important the type of decoration used in a ducach. Usually in holiday attire breast decorations consisted of one or two rows of dozens of different necklaces, ducaches and a cross. So along with the ducach was the coral necklace of various shapes and colors, a cross on a chain and necklace of beads (usually blue). Therefore ducaches allow us to see the development of craftsmanship and aesthetic preferences of our ancestors.

- So the value of the national symbol ranks as the embodiment of the unity of its people as is recognized by all cultures. Therefore, the use of certain elements of national costumes and their modernizing will always be relevant. In the use of decorations such as ducaches, a combination is possible with completely modern materials and items of clothing. So just as in times past, the ducach can be dominant decoration.

\section{REFERENCES}

Abramovych, S. (2002). Canon of Byzantine icon: Manual. Chernivtsy: Ruta.

Derevianko, Y. P., Panzich, S. M., \& Ponomariov, O. S. (2012).Esthetic ideals of cultural heritage of the folk: monograph. In: O. S. Ponomariov (ed.), Esthetic ideals of cultural heritage of the folk, Kharkiv: Rarytety Ukrainy.

Kosmina, O. (2006a). Traditional Ukrainian clothes.- vol. I, „Polissya. Carpathian; Wooded steppe. Steppe. Kyiv.: Baltia-Druk.

Kosmina, O. (2006b). Traditional Ukrainian clothes, vol. II, Kyiv.: Baltia-Druk,

Kozlov, S. V. (2010a). Ukrainian folk women jewelry of the 19th - 20th centuries. Ducachs. Set of cards, Poltava: editor Physical person-entrepreneur Poltava.

Kozlov, S. V. (2010b). Ukrainian folk women jewelry of the 19th - 20th centuries. Necklaces. Set of cards. Poltava: editor Physical person-entrepreneur Poltava.

Masliichuck, V. L. (2007). Province on the crossroads of cultures: research on the history of Sloboda Ukraine of the 17th -19th centureas, Kharkiv: Kharkiv private museum of mansions.

Oi nastypala ta chorna khmara. Retrived July 1, 2013 from: http://mos-ukr-capella.ru/main. php?file=oi-nastypyla.

Oi pojikhav za snopamy. Retrived July 1, 2013, form http:/ /ensembles.ru/song/oj_poihav.

Spasky, I. G. (1970), Ducats and Ducachs of Ukraine. Kyiv: Naukova Dumka.

Vialets, A. F.,\& Bilous, L. S. (2010). The Museum of Ukrainian folk ornamental art. Kyiv: Mystetstvo.

Vorochynska, G. V. (2007). Ukrainian folk women jewelry of the 19th - beginning of the 20th centuries: Monograph. Kyiv: Rodovid. 